\title{
Author Correction: Nuclear lipid droplets derive from a lipoprotein precursor and regulate phosphatidylcholine synthesis
}

\author{
Kamil Sołtysik¹, Yuki Ohsaki ${ }^{1}$, Tsuyako Tatematsu', Jinglei Cheng ${ }^{1} \&$ Toyoshi Fujimoto (D) ${ }^{1}$
}

Correction to: Nature Communications https://doi.org/10.1038/s41467-019-08411-x, published online 28 Jan 2019.

The original version of this Article contained errors in the Abstract and Introduction, whereby CCTa was incorrectly defined as an abbreviation of CDP-choline diacylglycerol phosphotransferase $\alpha$, instead of CTP: phosphocholine cytidylyltransferase $\alpha$. This has now been corrected in both the PDF and HTML versions of the Article.

Published online: 12 March 2019

\begin{abstract}
(c) (i) Open Access This article is licensed under a Creative Commons Attribution 4.0 International License, which permits use, sharing, adaptation, distribution and reproduction in any medium or format, as long as you give appropriate credit to the original author(s) and the source, provide a link to the Creative Commons license,

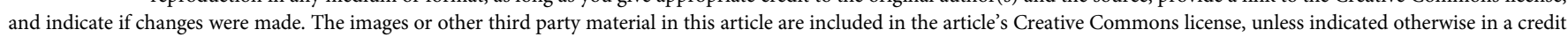
line to the material. If material is not included in the article's Creative Commons license and your intended use is not permitted by statutory regulation or exceeds the permitted use, you will need to obtain permission directly from the copyright holder. To view a copy of this license, visit http://creativecommons.org/licenses/by/4.0/.
\end{abstract}

(C) The Author(s) 2019

\footnotetext{
${ }^{1}$ Department of Molecular Cell Biology and Anatomy, Nagoya University Graduate School of Medicine, Nagoya 466-8550, Japan. These authors contributed equally: Kamil Sołtysik, Yuki Ohsaki. Correspondence and requests for materials should be addressed to Y.O. (email: yohsaki@med.nagoya-u.ac.jp) or to T.F. (email: tfujimot@med.nagoya-u.ac.jp)
} 